\title{
UTOPIAS OF KNOWLEDGE FORMS OF REPRESENTING THINKING IN THE CONTEXT OF AN EXHIBITION
}

Manuela Naveau'

\section{UTOPIAS DO CONHECIMENTO MO- DOS DE REPRESENTAR O PENSA- MENTO EM UMA EXPOSIÇÃO}

\section{RESUMO}

Se falamos da arte de pensar (GROYS, 2008) ou de exprimir pensamento através das artes (MERSCH, 20I5), o advento da pesquisa artística deu novo significado a processos de pensamento e pesquisa nas artes. Tais processos não só geraram novas formas de "obras" de arte; eles também exercem uma influência na apresentação, interação, mediação e reflexão, distribuição e arquivamento, e assumem assim um lugar importante em um mundo caracterizado pelo pensamento tecnocrático e processos de transformação em curso, um mundo no qual o conhecimento e o não-conhecimento parecem coexistir num estado de justaposição, com iguais valores. Como consequência, não precisamos - de imediato, para ser bem precisa - de espaços adicionais de pensamento que vão além dos espaços convencionais de pensamento, nos quais as relações de poder persistem - o das ciências e da universidade?

\section{PALAVRAS-CHAVE}

conhecimento; exposições; pesquisa artística

\begin{abstract}
Whether we're talking about the art of thinking (GROYS, 2008) or about thinking in the arts (MERSCH, 2015), the advent of art-based research has imparted new significance to processes of thinking and research in the arts. These processes not only generate new forms of artistic "works"; they also exert an influence on presentation, interaction, mediation and reflection, distribution and archiving, and therefore assume an important place in a world characterized by technocratic thinking and ongoing processes of transformation, a world in which knowledge and non-knowledge seem to coexist in a state of juxtaposition, each of equal value. As a result, don't we need-right now, to be precise-additional thought spaces that go beyond conventional spaces of thinking that reflects prevailing relationships of power-namely, that of the sciences and universities?
\end{abstract}

\section{KEYWORDS}

knowledge; exhibitions; artistic research

\footnotetext{
' Manuela Naveau (PhD), born 1972, is artist and curator of Ars Electronica Linz and teaches at University of Art and Design Linz. Her research investigates networks and knowledge in the context of computer based artistic practice.
} 


\section{Art and Research}

An exhibition entitled HYBRIDS opened in Athens in November 2016 following the invitation that the Onassis Cultural Centre had extended to Ars Electronica Linz to collaborate on a consideration of the subject of hybridity in the context of art. The question we asked ourselves was: What does it mean when art enters into a liaison with other disciplines? When artists who have no qualms about scientific experiments take part in such encounters, and thereby apparently skip to the beat on the dance floor of the scientific communities? What is contained by our understanding of artistic "works" and their spaces? What is thinking, what is meant by collaboration in this context, and what influence does this have on, for instance, authorship or on constantly changing objects on exhibit? Don't these approaches also call for new definitions and taxonomies? Or even a new language, and ultimately a new view and understanding of our world?

Curating this exhibition in Athens confronted us with a situation: the fact that research processes used by artists necessitate a special form of representation. The exhibition space hosted 16 artistic positions and processes, artifacts and works, as well as workshops and presentations dealing with the theme. The exhibition setting was a hybrid too, since the intention was to set up a space for experience and contemplation, one that showcases works, enables working processes, fosters reflection and permits participation. But to what extent did we differ from other institutions, conventional exhibition settings that allow for participative works and display the processual nature of constantly changing works? Or to phrase this issue in critical terms: What else would we have to do in order to live up to the claim of permitting, of showing, of representing thought processes in an exhibition space?

The discussion of art and its forms of representation flares up again in times of art-based research, artistic research, science art and hybrid art. Is this a matter of art after the end of art (see the book of that name by Arthur C. Danto) if it is neither clearly discernible when a work of art is a work of art, nor can one determine with absolute certainty the identity of the author behind it, and we are confronted by huge quantities of documents or inundated by video documentations as we go about trying to "understand" art? Can it be that art slices through the Gordian knot and

$$
\begin{aligned}
& \text { frees itself from the sublime attributes of transcendence and } \\
& \text { grandeur as well as from the incessant obligation of self-critique, of } \\
& \text { reflexively contemplating its own navel" in order to professionalize } \\
& \text { itself for "practices that refer to a broad spectrum of strategies } \\
& \text { which, although differently weighted and with other objectives, } \\
& \text { refuse to be outdone by the rigor and discipline of science's } \\
& \text { methodological principles (MERSCH, 20I5, P. 32)? }
\end{aligned}
$$

Is art in a relationship of rivalry with science or just aggressively flirting with it and reinventing itself in the process?2 Or perhaps art does not even have to undergo a total makeover, but rather just be able to discover new facets of itself and permit them to emerge. After all, the social transformation due to globalization and digitization mechanisms that has occupied so much of our

\footnotetext{
${ }^{2}$ One investigation of the question of the future of art has been ongoing since 20/3: an intensive collaborative project conducted by the Zurich University of the Arts (Department of Cultural Analysis) and the University of Cologne (Department of Art and Art Theory). In light of how massively our world has changed due to globalization and digitization measures, this must also necessarily have an influence on a changed conception of art. http://whtsnxt.net/about (accessed January I2, 20I7).
} 
attention must also exert an influence on a shift in art; otherwise, art would seem to be signing its own death sentence, and this would evidently bear out the pessimistic view of art held by Hans Bernhard of the artists' group ubermorgen. com, who stated:"Art becomes dead because it's only inside the system. Fucking boring. Suddenly, you're surrounded by nothing but references." 3 The essence of Hans Bernhard's criticism here is that art must dare to make the move beyond the confines of established art spaces. Now, this demand-even if it retains its validity-is nothing very new. Cautiously approaching new publics and calling into question the audience itself were already launched in Europe in the early 20th century by the Futurists, the Dadaists and Surrealists, and the artists of the Avant-garde4.And today as well, a hundred years later, we are still endeavoring, by entering into liaisons with other disciplines such as those in science and technology, not only to generate new artistic works but also, above all, to reach the new publics that come along with these "alien" disciplines and to elevate them to potential audiences for art. The combination of these new artforms and the situation of new "untrained" audiences calls for curators who can skillfully mediate the encounters among them, which, in turn, could explain why curating and curatorial studies boomed so hugely in the 1990s.

Thus, this is a matter of increasing focus on the processual, the interdisciplinary and the collaborative, or of conscious and voluntary, or even unconscious and involuntary, co-operation with "others" who can be categorized neither as artists nor spectators. This is a matter of works that are constantly changing and in motion, works that Umberto Eco already described in the late ' 50 s in an essay that formed the basis of his book The Open Work:

Science is the authorized field of insight into the world, and every striving by an artist in this direction-no matter how poetically productive it may be-labors under a misconception. The mission of art is not so much to comprehend the world than to bring out complements to it, autonomous forms that are added to those that already exist and reveal their own rules and personal life. At the same time, every artistic form may quite properly be regarded as, if not a surrogate for scientific understanding, then an epistemological metaphor. In other words, in every epoch, the way in which artforms structure themselves - through similarity, transformation into metaphors, in short, translation of a concept into a shapereflects the way that science, or even this particular epoch's culture in general, sees reality. (ECO, 1977, p. 46).

Umberto Eco ascribes to open works of art and, especially, to art works in motion above all a "function as epistemological metaphor" since conventional criteria of evaluation such as aesthetics and beauty are no longer effective. He argues:

\footnotetext{
$\ldots$ in a world in which the discontinuity of phenomena has called into question the possibility of a unitary, definitive worldview, it (the epistemological metaphor) shows us a way to see and thus recognize this world we live in, and to be able to integrate our sensibility.An open work of art faces the task of giving us a glimpse of the discontinuity-it does not give an account of it but rather is it. It mediates between the abstract category of science and the living material of our sensibility, and thus appears as a sort of transcendental schema that enables us to grasp new aspects of the world.(ECO, 1962, p. I59)
}

\footnotetext{
3 ubermorgen.com interview with the author conducted on May 25, 2014 in Vienna; audio and written transcript in the author's archive. See Naveau, Manuela (2017), Crowd and Art - Kunst und Partizipation im Internet, transcript Verlag, Bielefeld, p. 183.

4 See also Naveau, Manuela (2017), p. 55 and the following pages.
} 
What Umberto Eco so aptly put into words back in the late 1950s and early 1960s would soon, over the course of the ' 60 s, be put to the test in the USA. Interdisciplinary research began to be performed by EAT-Experiments in Art and Technology ${ }^{5}$ and it was provided with an institutional setting by György Kepes' founding of the Center for Advanced Visual Studies at MIT. Initially, these developments had scant influence on the European view of artistic research, ${ }^{6}$ according to Martin Tröndle and Julia Warmers, who acknowledge a hybrid form as a knowledge gain:

\begin{abstract}
After all, if (applied) artistic research actually does constitute something new, something qualitatively different that was not to be found previously in that form either in 'research' alone or in 'art' alone, then this term must surely refer to a hybrid of two practices-at least, this is a proposal conducive to productively expanding this field. (TRÖNDLE \& WARMERS, 20I2, p. 28)
\end{abstract}

What Tröndle and Warmers, in their elaborations on "hybrid," could not ascribe exclusively either to science or to art and, accordingly, allocated to a realm in between, is, in Eco's writings, clearly situated in the context of art: the epistemological metaphor, the work of art on the move.

\title{
Art and Research and Exhibiting
}

Countless publications dealing with the subject of art-based research seem to have appeared since the $1990 \mathrm{~s}^{7}$ and artistic research

\begin{abstract}
seems, all of a sudden, to have liberated art from out of the shadow of the sciences and not only to formulate a new mission for the arts but also to make a case for itself as a mode of research activity, of practice conducive to knowledge. (MERSCH, 2015, p. 19)
\end{abstract}

That this modified artistic practice must also necessarily have an influence on new forms of presentation and reflection in an exhibition context is to be expected, but this has been scarcely considered in the theoretical elaborations on this subject. That art-based research projects all-too-readily have recourse to tried-and-true forms of scholarly presentation-first and foremost, glass display cases and shelving units of exhibitions that take a historicist approach to their topic-is understandable, since these forms themselves imply research and thus inherently signal a scholarly mode of dealing with the material on display. That thinking in the arts, exhibiting knowledge, and opening of the exhibition space as a setting for thinking conducive to insight does not necessarily have to be done by means of a space containing serially arrayed artifacts conserved under glass as "pseudoscientific" art installations is a position I would now like to

\footnotetext{
${ }^{5}$ EAT - Experiments in Art and Technology was an interdisciplinary partnership of individuals, including Billy Klüver, a Swedish engineer who worked for Bell Telephone Laboratories in New Jersey, and New York-based artists Robert Rauschenberg, John Cage, David Tudor, Yvonne Rainer, Deborah Hay, Robert Whitman, Steve Paxton, Alex Hay, Lucinda Childs and Öyvind Fahlström, whose first collaborative performances in October 1966 in New York were entitled 9 evenings:Theatre and Engineering.

I was inspired by Siegfried Zielinski's text on artistic research and art as experiment, "Thinking about Art after the Media: Research as Practised Culture of Experiment" (ZIELINSKI, 20I0, p.304) in its entirety, but especially by his mention of one of the world's first interdisciplinary labs. The House of Wisdom was a library in Bagdad during the Golden Age of Arabic-Islamic science (circa 700-I200 AD), when scholars in a wide array of disciplines gathered, translated Ancient Greek texts, did trail-blazing research and conducted experiments - for instance, with hydraulic and pneumatic systems. Among the spinoffs was the world's first programmable flute-playing automaton invented by the Banu Musa Brothers.

${ }^{6}$ Also see Tröndle and Warmers, 2012, p. 23:"'In this 'narrative of cooperation' among practitioners of art and science, the natural scientists and engineers appear to have been the initiators most of the time. It is astounding that they seem to have had far fewer reservations about getting involved with artists than scholars in the social sciences and humanities do."

${ }^{7}$ Mersch, a philosopher, currently lists about 16 publications on this topic, and also cites journals and internet publications.
} 
briefly argue by invoking Umberto Eco's epistemological metaphor and applying it to three selected works of art in the HYBRIDS exhibition produced by Ars Electronica Linz in Athens.

Paolo Cirio's Loophole for All (Figure I) is an installation that takes a closeup look at offshore financial centers like the Cayman Islands. The Italian artist, hacker and activist holds the opinion that "everyone should have the possibility of exploiting the same tax benefits that major corporations are constantly taking advantage of.' 8 Accordingly, he offers certificates that exhibition visitors can simply hijack, documents that permit the holder to profit from those same tax advantages. In a city like Athens, from which many firms have relocated to Cyprus to escape high tax rates, this work seems to be especially relevant, but two stacks of certificates are not the only elements that make up the appeal of the exhibition setting. Above all, the artist succeeds in using space-filling infographics to call attention to and to elucidate the mechanisms behind the loopholes-what you need to get registered on the Cayman Islands and who has been enjoying life in this tax haven.

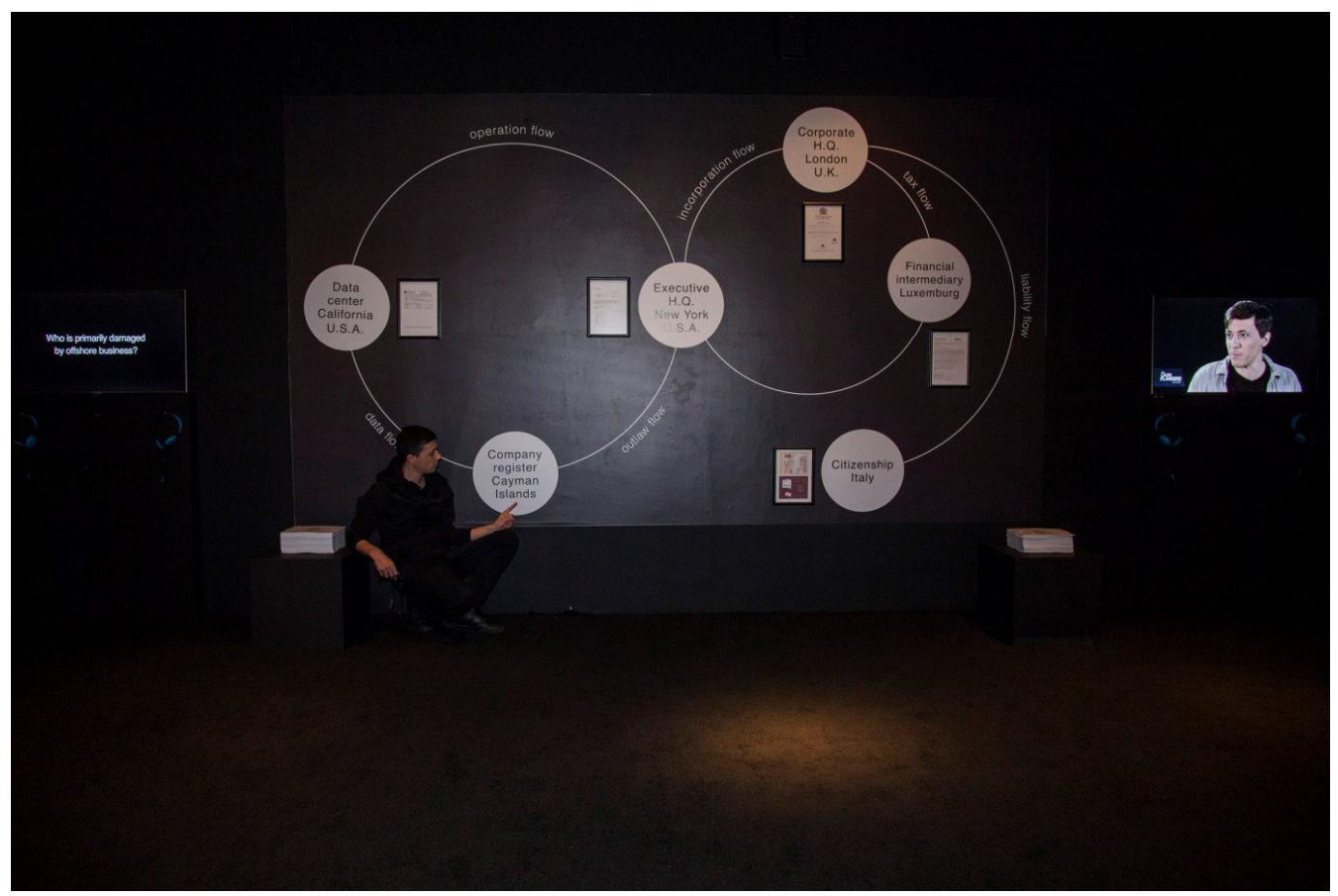

Figure I - Loophole for All, photo showing Paolo Cirio explaining the work; photo credit: Andreas Simopoulos, courtesy of Onassis Cultural Centre-Athens

Artist/hacker Paolo Cirio's experiment entailed his own identity and his own body. As an Italian citizen, he founded a firm registered in London and then proceeded to publish the names and tax ID numbers of firms listed on the Cayman Islands on www.loophole4all.com and at a data center in California. He sold the identities of the listed firms for $€ 0.99$ apiece from a Luxembourg address with payment via PayPal. Over 900 bids were received by the abovementioned website. This action-the massive theft of the company names that Cirio then purveyed-profited precisely from the anonymity and the

\footnotetext{
${ }^{8}$ This quote was taken from a blog posting about the project: http://www.aec.at/aeblog/de/2014/08//4/ loophole-for-all-steuerfreiheit-fur-allel (accessed on January 25, 2017).
} 
presumption of secrecy by these offshore financial centers and thus hit this system right where it lives. The www.loophole4all.com website is not present in the exhibition, even if the descriptive text on site makes it clear that this is a matter of an online project. Documents-for instance, a copy of Paolo Cirio's passport, an excerpt from the company register in the UK, and an e-mail from PayPal sternly informing Cirio of his account's cancellation because his transactions violate PayPal's usage guidelines - supplement the infographics.

Thus, the original work's primarily digital components were materialized and visualized for the exhibition in the form of infographics, physical certificates and accompanying video documentations, including interviews conducted by the artist with financial experts to get across this complex issue. This creates a space for experience and thought that relates more than the sum of its individual parts and knows more than the artist alone could ever know.

The work Hare's Blood + by Lucie Strecker and Klaus Spiess can be understood in a similar vein (Figures 2 and 3). For the German dramaturge and the Austrian physician/anthropologist, artifacts, infographics and accompanying video documentation provide important details of their research.

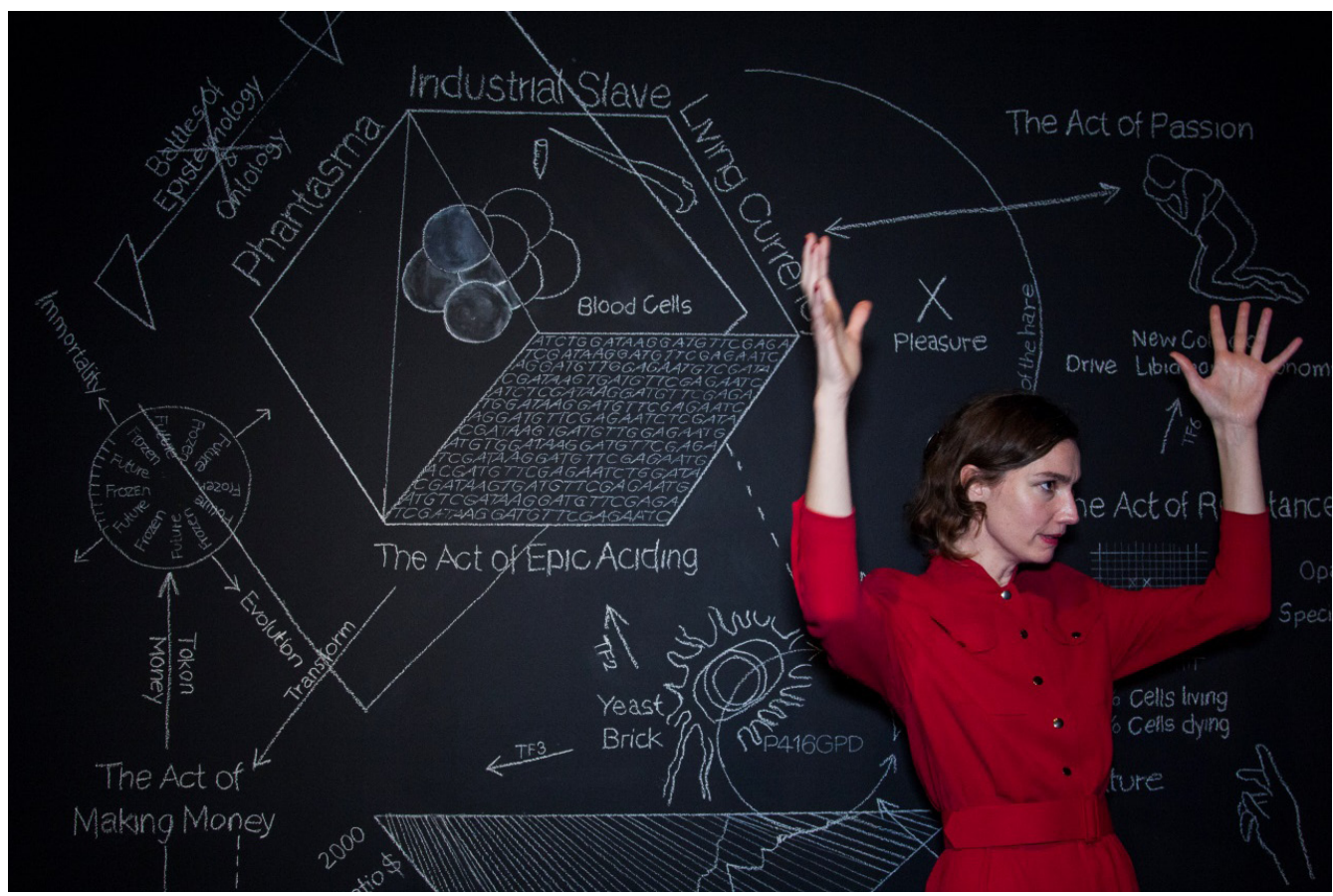

Figure 2 - Hare's Blood +, photo showing Lucie Strecker explaining the work; photo credit: Andreas Simopoulos, courtesy of Onassis Cultural Centre-Athens

Their work is a biotechnological live performance and installation; it also deals with the subject of DNA as living currency. They appropriated a work of art by Joseph Beuys entitled Hasenblut, and reconfigured it as Hare's Blood +. They opened one of the two hundred multiples, extracted the DNA and isolated the gene from Beuys' original work of art-the one that protects the creature from oxidative stress and is responsible for aging. In a Petri dish (resembling the one used in the original) containing a yeast solution, the blood cells are brought to life and their growth nurtured in coordination with the trend of stock market averages and the bids entered at an auction of the work of art conducted on site. At the time the Petri dish was sold, $67 \%$ of the cells were alive and $33 \%$ 
were dead. In the exhibition, the artists attempt to keep the temperature at a constant $4-6^{\circ} \mathrm{C}$ to maintain precisely this ratio, and they present the dead material from Beuys' work juxtaposed to their cooled, activated synthetic gene, a full-wall infographic and a video of the previously conducted auction.

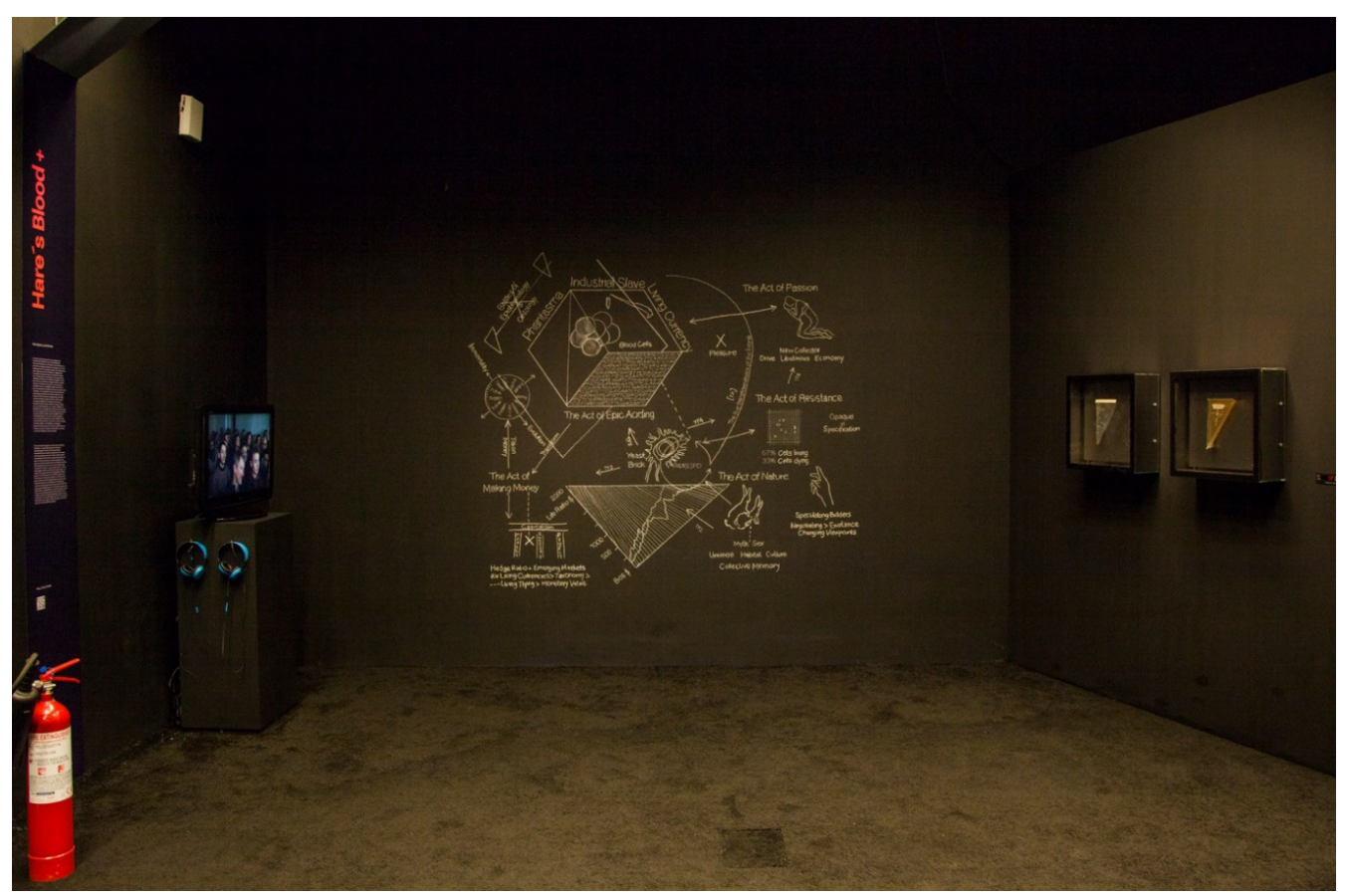

Figure 3 - Hare's Blood +, view of the installation; photo credit:Andreas Simopoulos, courtesy of Onassis Cultural Centre-Athens

Gilberto Esparza's work Plantas Autofotosintéticas (Figure 4) also created an organism in the exhibition space. Suspended in the middle of it is a spherical Plexiglas tank containing plants and fish; connected to it are numerous tubes and filtration equipment that make this contraption resemble a huge spider. It is actually a compact facility to treat waste water and simultaneously generate energy via microbial fuel cells and bacteria. In addition to conducting a scientific experiment, this artistic installation includes a strong social component since, prior to the opening of each installation, the artist conducts a fact-finding investigation of local waste water treatment. He contacts the firms involved, requests samples from various sites around the city in which his work of art is being shown, and fills his tank with local sewage. Thus, each new exhibition location brings his work to life anew and imparts to it a rhythmic pulse engendered by the water flowing through the system, coursing through the organism. 


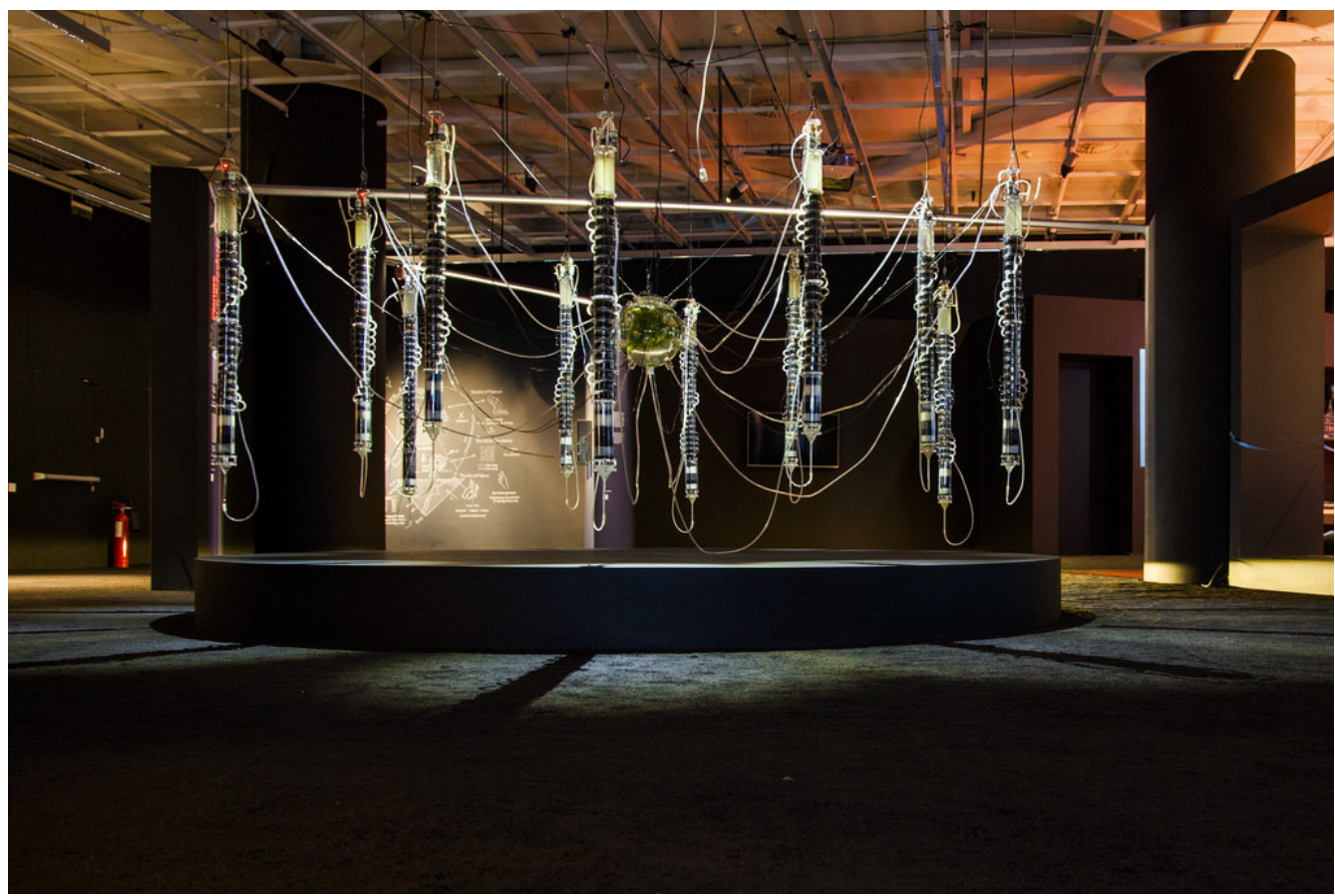

Figure 4 - Plantas Autofotosintéticas view of the installation; photo credit: Andreas Simopoulos, courtesy of Onassis Cultural Centre-Athens

The interviews and conversations with the individuals involved in the process flow into the exhibition setting in the form of video documentation. Moreover, the artist offers a sonification of the metabolic processes occurring in the exhibition space. He formulated his interest in developing the work further in these terms:

\begin{abstract}
I am now developing a project that will explore the most polluted rivers in Mexico in order to study water quality and interview affected communities, scientists, and activists, as well as the creation of a sound instrument that can be used to measure the bacteria levels in rivers and translate that information into different sounds that vary according to the type of contaminants present in the water. The final product will be a disc with the information and sound bits gathered during my investigation as well as a web page for researchers and the general public who are interested in learning more about the current status of our rivers. 9
\end{abstract}

Since all three works are matters of artistic processes that were already launched prior to the Athens exhibition's run and involved other individuals besides the artists themselves, it was particularly important for us to permit the artists to provide personal accounts of their processes. Accordingly, we not only invited the artists to install their works in Athens; we deemed it essential that they also got to talk about the development of their work over time, give an account of its origins, relate incidents and anecdotes, and elaborate on their artistic practice in general. At several meetings with the Onassis Cultural Center's educational staff and the curators and initiators of the exhibition, the artists spoke about the processes they conducted and their world, one that encompasses art, activism, science and social commitment. Furthermore, the discussions in the exhibition space were made accessible by the general public

\footnotetext{
${ }_{9}$ This quote was taken from a blog posting about the project: http://www.aec.at/aeblog/en/2015/07/27/ kuenstlerische-denkanstoesse-fuer-die-oekologische-entwicklung/ (accessed on January 25, 2017).
} 
in the context of a suitably programmed series of events. Addresses by the participating artists and invited scholars rounded out the ancillary program staged in conjunction with the HYBRIDS exhibition.

\section{Summary and Conclusion}

Progress in the sciences and the technology sector determine our world. We perceive our world primarily via monitor screens and filter systems on which we can exert scant influence. Cultural and social development constantly lags behind the incessantly shifting digital reality. This makes it ever more important for there to be artists who are interested in what technocrats advance and support, who critically scrutinize these developments and who reflect on our social trends. ${ }^{10}$ Nevertheless, critique of the status quo is just one side of the coin. Fiction and utopia are important methods used by artists who, while grounding their work in what is happening in the world right now, also conceptualize a potential future and even draw up fictional blueprints for utopias of knowledge. We have to nurture artists who are able to think up a utopia of knowledge and who critically confront us with new forms of knowing and not-knowing. The exhibition space is used here as a space for thinking, and not only showcases artifacts of processes that took place in the past but also must be regarded and utilized in its interdisciplinary entirety as a space-online as well as offline-for the presentation of objects and subjects, for interactions among art, artist, scientist and audience in association with mediators, curators, producers and institutions, for the purpose of active further development of hypotheses, for a new thinking and knowledge that is not based exclusively on spoken words but also on aesthetic designs and artistic metaphors that invite those who behold them to go beyond knowledge to communication.

\section{References}

ECO, Umberto. Das offene Kunstwerk, (zweite Auflage, Originalausgabe Opera aperta, Mailand 1962), Frankfurt am Main, 1967.

GROYS, Boris. Die Kunst des Denkens. Philo Fine Arts, Hamburg, 2008.

MERSCH, Dieter. Epistemologien des Ästhetischen. diaphanes, Zürich-Berlin, 2015.

NAVEAU, Manuela. Crowd and Art - Kunst und Partizipation im Internet. transcript Verlag, Bielefeld, 2017.

TRÖNDLE, Martin und WARMERS, Julia. Kunstforschung als ästhetische Wissenschaft, transcript Verlag, Bielefeld, 2012.

Artigo recebido em março de 2017.Aprovado em maio de 2017.

\footnotetext{
${ }^{10}$ That these new artistic practices necessitate not only a shift in aesthetics but also in the way we deal with artistic works and that they demand innovative curatorial approaches are given detailed and comprehensive treatment by Beryl Graham and Sarah Cook in their 2010 book Rethinking Curating. The authors' point is that an appropriate treatment of media-based artistic works necessarily entails new forms of presentation, communication, reflection, distribution as well as collecting and conserving, and thus they also address the increasingly important question of how institutions ought to deal with digital art.
} 